\title{
PENERAPAN MODEL PEMBELAJARAN KONTEKSTUAL PADA PELAJARAN MENULIS DI KELAS IX
}

\author{
Ni Wayan Sriati \\ SMP Negeri 4 Singaraja, Buleleng, Indonesia \\ e-mail: sriati4sgr@gmail.com
}

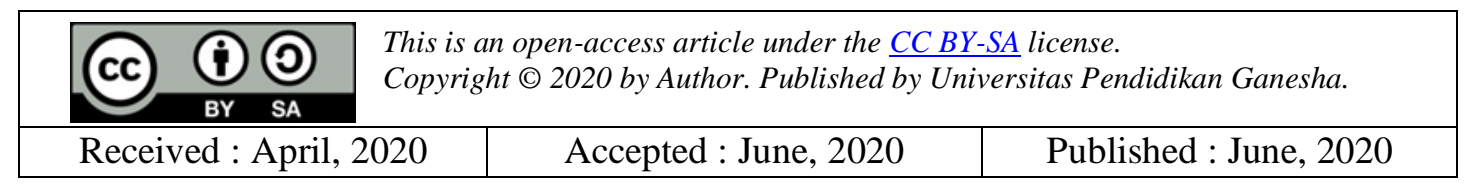

\begin{abstract}
ABSTRAK
Penelitian ini dilakukan dengan tujuan untuk mengetahui apakah model pembelajaran kontekstual dapat meningkatkan prestasi belajar siswa kelas IX B5 di SMP N 4 Singaraja dalam keterampilan menulis. Subjek penelitian ini adalah siswa kelas IX B5 di SMP N 4 Singaraja tahun ajaran 2018/2019. Kelas ini terdiri dari 30 siswa, yaitu 15 pria dan 15 wanita. Penelitian ini didahului dengan melakukan observasi awal yang mengindikasikan banyak siswa yang mengalami permasalahan dalam menulis. Penelitian ini dirancang dengan menggunakan metode penelitian tindakan kelas. Terdapat dua siklus dalam penelitian ini. Setiap siklus berisikan tindakan/penerapan model pembelajaran kontekstual dan diakhiri dengan memberikan tes menulis. Metode pengumpulan datanya adalah tes keterampilan menulis. Metode analisis datanya adalah deskriptif. Hasil analisis data menunjukkan bahwa terjadi peningkatan keterampilan menulis siswa setelah melalui setiap siklus. Pada Pre-test skor rata-rata siswa dalam menulis adalah 73.2 yang menunjukkan bahwa skor rata-rata tersebut berada di bawah Target Pencapaian Minimal (TPM) yaitu 77. Setelah dilakukan proses siklus ke-1 nilai rata-rata siswa meningkat menjadi 78.67. Dari hasil tersebut dapat dilihat bahwa terjadi peningkatan dalam keterampilan siswa yang sudah dapat mencapai TPM. Setelah dilakukan siklus ke-2 nilai rata-rata siswa juga mengalami peningkatan yaitu menjadi 83.33. Dapat disimpulkan bahwa model pembelajaran kontekstual dapat meningkatkan keterampilan menulis siswa.
\end{abstract}

Kata-kata kunci: model pembelajaran kontekstual, prestasi belajar, menulis

\section{ABSTRACT}

This research was aimed at improving students' writing competency by implementing contextual teaching and learning model at IX B5 class in SMP N 4 Singaraja. The subjects of this study were students of IX B5 class at SMP N 4 Singaraja in the academic year 2018/2019. This class consisted of 30 students, namely 15 males and 15 females. This research was preceded by conducting pre observations which indicated that many students faced some problems in writing class. This research was designed by using classroom action research method. There were 2 cycles conducted in this research. Each cycle contained the implementation of contextual learning model and was ended by writing test. The data collection method used a writing test. The results of data analysis showed that there was an increase in students' writing skills after each cycle done. In the Pre-test the students' mean score was 73.2 which showed that it was below the school criteria (77). After the process of cycle 1 conducted, the students' mean score increased to 78.67. From these results it could be seen that an improvement of students' writing achievement that could reach school criteria. After cycle 2 done, the students' mean score also 
increased to 83.33. It could be concluded that the contextual teaching learning model can improve students' writing skills.

Keywords: contextual teaching learning model, writing, writing achievement

\section{PENDAHULUAN}

Pendidikan adalah usaha sadar dan terencana untuk mewujudkan suasana belajar dan proses pembelajaran agar peserta didik secara aktif mengembangkan potensi dirinya. Untuk memiliki kekuatan spiritual keagamaan, pengendalian diri, kepribadian dan akhlak mulia, serta keterampilan yang diperlukan dalam masyarakat, bangsa dan negara. Berbagai usaha pembaharuan kurikulum, perbaikan sistem pengajaran dan peningkatan kualitas kemampuan guru merupakan suatu upaya ke arah peningkatan mutu pembelajaran. Banyak hal yang dapat ditempuh untuk mencapai tujuan tersebut, salah satunya adalah bagaimana cara menciptakan suasana belajar yang baik, mengetahui kebiasaan dan kesenangan belajar siswa agar siswa bergairah dan berkembang sepenuhnya selama proses belajar berlangsung. Untuk itu seharusnya guru mencari informasi tentang kondisi mana yang dapat meningkatkan pembelajaran di sekolah.

Dalam kurikulum sekolah SMP disebutkan bahwa untuk menguasai bahasa Indonesia dengan baik, siswa diharapkan untuk menguasai empat keterampilan bahasa yaitu keterampilan mendengarkan, membaca, berbicara, dan menulis. Komponen bahasa lain seperti pengucapan, tata bahasa, dan kosa kata juga diajarkan untuk mendukung pengembangan keempat keterampilan bahasa tersebut.

Menulis adalah salah satu dari empat keterampilan bahasa yang harus dikuasai dalam rangka untuk menguasai bahasa Indonesia dengan baik. Pengajaran menulis bertujuan untuk memimpin siswa dalam mencapai beberapa kompetensi yang mengharuskan mereka untuk mampu dalam mengekspresikan ide-ide mereka dalam bentuk tertulis. Standar kompetensi penulisan meliputi standar isi dan standar kinerja, yang berkaitan dengan pengetahuan, keterampilan, sikap, dan pemahaman tingkat. Di sisi lain, sebagai rincian standar kompetensi, kompetensi dasar adalah pengetahuan, keterampilan, dan tingkat minimum yang harus dikuasai dan dilakukan oleh siswa dalam standar masing-masing. Selanjutnya, untuk mengetahui apakah kompetensi dasar dapat dicapai oleh siswa, beberapa indikator harus dirumuskan.

Menurut Raimes (1983:54) mengajar menulis adalah penting karena tiga alasan yaitu yang pertama adalah bahwa menulis memperkuat struktur tata bahasa, idiom, dan kosa kata. Alasan kedua adalah ketika siswa menulis, mereka memiliki kesempatan untuk menjadi petualang dengan bahasa. Alasan ketiga adalah bahwa siswa menjadi lebih terlibat dalam bahasa, terlibat dengan diri mereka sendiri dan pembacanya. Karena faktafakta di atas, kita dapat melihat dengan jelas tujuan keseluruhan pengajaran menulis adalah memungkinkan para siswa untuk mengekspresikan ide-ide dan pikiran mereka dalam bentuk tertulis.

Karena menulis adalah kegiatan yang kompleks, maka dianggap sulit bagi siswa untuk menulis tulisan yang baik dalam waktu singkat. Menurut Chakraverty dan Gautum (2001) menulis adalah aktivitas reflektif yang membutuhkan cukup waktu untuk berpikir tentang topik yang spesifik, untuk menganalisis dan mengklasifikasikan setiap latar belakang pengetahuan. Ini berarti menulis mengintegrasikan beberapa proses, seperti: mencari topik, memberikan informasi untuk mendukung topik, mengelompokkan ide-ide, 
pengorganisasian ide dalam urutan logis dan menerapkan pengetahuan linguistik. Dapat disimpulkan bahwa menulis adalah proses yang berkesinambungan yang memerlukan beberapa tahap. Akibatnya, para siswa harus diberi waktu yang cukup untuk menyelesaikan tulisan mereka. Oleh karena itu, siswa yang terlibat dalam kegiatan menulis cenderung menghadapi banyak masalah selama proses penulisan.

Sebagian besar siswa merasa kesulitan dalam mengembangkan ide-ide dalam pikiran mereka. Sebenarnya, mereka mungkin memiliki sesuatu untuk menyatakan dalam pikiran mereka, tetapi mereka sering bingung untuk mengekspresikan dan mengembangkan ide-ide mereka menjadi sebuah tulisan yang baik. Ini adalah suatu masalah umum yang dihadapi oleh sebagian besar guru bahasa Indonesia dalam pengajaran menulis. Campbell (2002) menyatakan bahwa masalah terbesar yang siswa miliki dalam menulis adalah bahwa mereka tidak dapat menempatkan ide-ide mereka dan fakta ke dalam kertas karena mereka takut jika ide-ide mereka tidak dapat ditulis dengan benar dalam hal tata bahasa. Kondisi ini menyebabkan timbulnya kecemasan pada siswa. Selain itu, Chakraverty dan Gautum (2001) menyatakan lebih lanjut bahwa salah satu masalah siswa adalah bahwa mereka memiliki kesulitan dalam mengatur informasi atau ide-ide logis untuk mencapai koherensi dalam tulisan mereka, yang merupakan persyaratan utama dalam menulis.

Hal ini juga dialami oleh siswa yang ada di kelas IX B5 SMP Negeri 4 Singaraja dimana nilai siswa pada mata pelajaran Bahasa Indonesia khususnya dalam keterampilan menulis ternyata masih jauh di bawah Kriteria Ketuntasan Minimal (KKM) yaitu 73.2; sedangkan KKM mata pelajaran Bahasa Indonesia adalah 77. Masalah tersebut disebabkan oleh kemampuan guru menggunakan model-model pembelajaran yang baru seperti model konstruktivistik masih belum sesuai harapan, para siswa di kelas ini banyak yang kemauan belajarnya rendah, serta masih kurangnya sarana dan prasarana yang mendukung dalam proses pembelajaran.

Di samping permasalahan di atas upaya yang dilakukan guru dalam pembelajaran menulis cenderung hanya melalui pemberian penjelasan secara teori menulis, kemudian guru menugaskan siswa menulis dengan topik bebas atau topik yang ditentukan. Cara yang dilakukan oleh guru tersebut masih berorientasi produk bukan proses. Upaya tersebut tidak membimbing dan tidak memberi pengalaman kepada siswa secara ilmiah untuk menemukan sendiri dan belajar memecahkan masalahnya sendiri karena pola pembelajarannya masih berorientasi pada guru (teacher center) yang seharusnya diorientasikan pada siswa (student center). Kelas masih berfokus pada guru sebagai sumber utama pengetahuan sehingga kurang memberdayakan siswa mengkonstruksikan pengetahuannya di benak mereka sendiri. Kondisi ini perlu segera diatasi yaitu dengan menemukan langkah-langkah praktis dalam pembelajaran menulis deskripsi yaitu melalui penerapan pembelajaran kontekstual.

Implementasi model kontekstual (contextual teaching learning) mengarah pada upaya meningkatkan mutu pengajaran dan pembelajaran di tingkat pendidikan dasar dan menengah untuk mempersiapkan peserta didik menghadapi tantangan masa depan (Rudiyanto, 2009). Model kontekstual (contextual teaching learning) dapat membantu guru mengaitkan materi-materi yang diajarkannya dengan situasi dunia nyata. Model ini mendorong siswa membuat hubungan antara pengetahuan yang dimilikinya dengan penerapannya dalam kehidupan sehari-hari sebagai anggota keluarga dan masyarakat. Disinilah diperlukan materi yang otentik agar pembelajaran lebih bermakna. Penggunaan 
sumber belajar lingkungan dapat meningkatkan hasil belajar dan meningkatkan mutu pembelajaran. Proses pembelajaran berlangsung secara alamiah yaitu siswa bekerja dan mengalami, sehingga hasil pembelajaran lebih bermakna bagi siswa. Berhubungan dengan menulis deskripsi, dapat dikatakan bahwa pembelajaran kontekstual dapat membantu siswa dalam menyusun ide dan mengembangkan kreativitas siswa dalam menyusun teks deskripsi. Siswa dapat mengembangkan idenya melalui contoh nyata yang diberikan oleh guru pada waktu pembelajaran berlangsung. Ini membantu siswa untuk mengatur arus informasi yang dinyatakan dalam setiap kalimat dalam tulisan mereka (Slavin, 1999).

Contextual Teaching and Learning (CTL) merupakan konsep belajar yang membantu guru mengaitkan antara materi yang diajarkan dengan fakta dalam kehidupan siswa. CTL lebih menekankan pada rencana kegiatan kelas yang dirancang guru (Suyanto, 2003). Rencana kegiatan tersebut berisi skenario tahap demi tahap tentang apa yang akan dilakukan bersama siswanya sehubungan dengan topik yang akan dipelajari. Pembelajaran kontekstual lebih mementingkan strategi belajar bukan hasil belajar. Pembelajaran kontekstual mengharapkan siswa untuk memperoleh materi pelajaran meskipun sedikit tetapi mendalam, bukan sebaliknya, banyak tetapi dangkal.

Penggunaan $C T L$ dalam pembelajaran bahasa dan sastra Indonesia di kelas dapat menarik perhatian siswa karena $C T L$ memiliki berbagai komponen sehingga pembelajaran tidak membosankan. Menurut Suyanto (2003:1) CTL dapat membuat siswa terlibat dalam kegiatan yang bermakna yang diharapkan dapat membantu mereka mampu menghubungkan pengetahuan yang diperoleh di kelas dengan konteks situasi kehidupan nyata.

Dalam proses belajar di kelas, siswa dibiasakan untuk saling membantu dan berbagi pengalaman dalam kelompok masyarakat belajar (learning community). Dalam proses belajar, guru perlu membiasakan anak untuk mengalami proses belajar dengan melakukan penemuan dengan melakukan pengamatan, bertanya, mengajukan hipotesis, mengumpulkan data, analisis data, dan menarik kesimpulan (inquiry). Seluruh proses dan hasil belajar diukur dengan berbagai cara dan diamati dengan indikator yang jelas (auhentic assessment). Setiap selesai pembelajaran guru wajib melakukan refleksi terhadap proses dan hasil pembelajaran (reflection) (Syahraini, 2014).

Melalui pemikiran dari penjelasan di atas tentang pembelajaran kontekstual yang digunakan dalam pengajaran menulis dan permasalahan yang sering dihadapi dalam pembelajaran, peneliti menerapkan model pembelajaran kontekstual untuk meningkatkan keterampilan menulis teks deskripsi pada siswa kelas IX B5 SMP Negeri 4 Singaraja.

\section{METODE}

Tulisan ini adalah hasil penelitian tindakan kelas. Tujuan utama penelitian tindakan kelas ini adalah untuk memecahkan permasalahan nyata yang terjadi di dalam kelas, juga sekaligus mencari jawaban ilmiah bagaimana hal tersebut dapat dipecahkan dengan tindakan yang dilakukan. Menurut Kemmis \& McTaggart (1988), sebuah penelitian tindakan kelas adalah proses siklus yang terus menerus dilakukan oleh peneliti sampai standar minimum atau nilai kelulusan tercapai. Siklus terdiri dari perencanaan, tindakan, observasi, dan refleksi.

Tujuan dari penelitian ini adalah untuk meningkatkan kompetensi siswa dalam menulis melalui penerapan model pembelajaran kontekstual. Subyek penelitian ini adalah 
siswa kelas IX B5 di SMP Negeri 4 Singaraja pada tahun akademik 2018/2019. Ada 30 siswa di kelas yang terdiri dari 15 laki-laki dan 15 perempuan. Berdasarkan pengamatan dan wawancara awal, para siswa dipilih karena siswa memiliki masalah dalam menulis terutama untuk dalam mengembangkan ide. Sedangkan yang menjadi objek penelitian ini adalah peningkatan aktivitas dan keterampilan menulis siswa kelas IXB5 SMP Negeri 4 Singaraja setelah model pembelajaran kontekstual diterapkan dalam proses pembelajaran.

Peneliti menggunakan beberapa instrumen dalam mengumpulkan data yaitu dengan menggunakan tes dan catatan buku harian. Ada dua jenis tes menulis yang digunakan dalam penelitian ini: Pre-test dan post-test. Pre-test diberikan sebelum memberikan tindakan untuk mengetahui kompetensi awal siswa dalam menulis. Sementara itu, post-test diberikan pada akhir setiap siklus untuk mengetahui kompetensi siswa dalam menulis setelah tindakan diberikan. Post-test diberikan untuk mengetahui apakah kompetensi siswa telah membaik atau tidak.

Test kompetensi menulis (post-test) dibuat untuk mengukur tingkat kompetensi siswa menulis selama periode percobaan. Tes ini merupakan esai tes di mana siswa ditugaskan untuk menulis sebuah tulisan. Kompetensi menulis siswa diukur dengan berfokus pada empat dimensi penulisan, yaitu: konten dan pengembangan, organisasi, tata bahasa dan struktur, kosakata dan gaya. Setiap dimensi memiliki bobot yang berbeda, tetapi berbagai nilai yang sama untuk semua dimensi. Setiap dimensi ditentukan atau dijelaskan oleh beberapa indikator.

Rubrik skor analitis digunakan untuk menilai kinerja tugas siswa. Rubrik adalah alat penilaian yang berisi daftar kriteria untuk sebuah pekerjaan atau apa account dan mengartikulasikan gradasi kualitas untuk setiap kriteria dari sangat baik untuk miskin (Goodrich, 1997). Dalam penelitian ini, rubrik skor analitis akan digunakan untuk menilai kinerja siswa. Tingkat skor analisis rubrik atau skor secara terpisah bagian atau karakteristik produk atau proses pertama, kemudian, jumlah, nilai ini bagian untuk mendapatkan skor total. Rubrik penilaian yang dikembangkan dalam penelitian berdasarkan kinerja siswa dalam menulis. Skor tertinggi adalah 100.

Buku harian digunakan oleh peneliti untuk mengambil catatan kegiatan kelas selama proses pembelajaran. Itu digunakan untuk merekam perilaku siswa dan kondisi kelas selama kegiatan belajar mengajar. Data dari buku harian peneliti digunakan untuk mengetahui permasalahan siswa selama proses belajar mengajar, sehingga peneliti dapat membuat keputusan tentang apa yang harus dilakukan untuk meminimalkan masalah ini untuk mendapatkan hasil yang lebih baik dalam setiap siklus.

Tindakan dalam penelitian ini dilakukan sesuai dengan prosedur, yang terdiri dari perencanaan, tindakan, observasi, dan refleksi. Prosedur dapat dilihat sebagai berikut:

\section{Pre-test}

Pre-test digunakan untuk menguji kompetensi siswa dalam menulis sebelum tindakan diberikan. Kemudian hasil pre-test digunakan sebagai acuan dalam melakukan penelitian.

\section{Siklus}

Tiap siklus dilakukan dalam tiga sesi. Dua sesi yang ditujukan untuk tindakan dan satu sesi dimaksudkan untuk ujian a.Perencanaan 
Selama tahap perencanaan, ada sejumlah kegiatan yang disiapkan oleh peneliti, yaitu: 1) Menyiapkan topik yang diajarkan untuk setiap siklus; 2) Mempersiapkan topik dan teks yang digunakan; 3) Menyiapkan skenario belajar mengajar 4) Mempersiapkan pertanyaan untuk post-test; 5) Mempersiapkan kuesioner yang akan digunakan untuk mengetahui respon siswa terhadap strategi yang digunakan.

b. Tindakan

Aksi yang melibatkan proses pengajaran dan pembelajaran. Ada tiga kegiatan utama dalam rencana pelajaran, yaitu: pra-aktivitas, aktivitas, dan pasca-aktivitas.

\section{c. Observasi}

Langkah ini digunakan untuk mengetahui hasil dari tindakan dalam setiap siklus. Kompetensi siswa dalam proses pembelajaran dapat dilihat dari hasil post-test. Respon siswa dan perasaan terhadap tindakan yang diberikan yang diketahui dari hasil kuesioner.

\section{d.Refleksi}

Refleksi dilakukan pada akhir tindakan. Pada tahap ini, perbaikan siswa dievaluasi berdasarkan pada hasil post-test. Melalui refleksi ini, peneliti melihat apakah perbaikan telah mencapai target atau tidak. Tindakan dihentikan jika 100 persen dari subjek total kelas telah mencapai atau melewati indikator pencapaian skor rata-rata minimal 77. Jika tidak, penelitian dilanjutkan dengan siklus berikut jika 100 dari seluruh subjek tidak dicapai atau melewati skor indikator pencapaian minimum yang diusulkan di atas.

Data diperoleh dari hasil pre-test dan post-test. Pre-test dilakukan sebelum pelaksanaan tindakan. Post-test akan menunjukkan hasil dari tindakan selama pembelajaran. Hasil post-test dibandingkan dengan hasil pre-test untuk menentukan peningkatan keterampilan menulis siswa. Jika skor rata-rata post-test lebih tinggi dari skor rata-rata pre-test itu berarti bahwa tindakan itu efektif untuk meningkatkan keterampilan siswa dalam menulis. Jenis-jenis data yang terkumpul dalam penelitian ini adalah dalam bentuk data kualitatif dan kuantitatif. Data kualitatif dikumpulkan dari buku harian peneliti. Sedangkan, data kuantitatif dikumpulkan dari hasil pre-test, post-test dari setiap siklus. Hasil tes dianalisis secara deskriptif, untuk mengetahui nilai rata-rata pretest dan post-test setiap siklus. Penelitian ini akan dianggap berhasil jika100\% dari siswa telah melewati standar nilai kelulusan $\geq 77$. Hal ini didasarkan pada nilai kelulusan standar yang diterapkan di sekolah untuk mata pelajaran Bahasa Indonesia, yaitu 77.

\section{HASIL DAN PEMBAHASAN}

Tujuan penelitian ini adalah untuk meningkatkan keterampilan menulis siswa maka bagian ini membahas bagaimana perbaikan diraih oleh siswa selama perawatan berlangsung. Peningkatan tersebut dapat dilihat dari hasil analisis buku harian peneliti dan hasil tes.

Dari buku harian peneliti, diketahui bahwa ada perubahan perilaku siswa selama proses belajar-mengajar. Pada siklus I, beberapa siswa yang pasif dan sebagian besar dari mereka merasa tidak percaya diri saat memberikan jawabannya. Mereka memiliki kecenderungan untuk menunggu jawaban teman-teman mereka dan hanya setuju 
jawabannya. Selain itu, siswa juga menghadapi masalah dalam memahami kata-kata dari teks yang diberikan. Beberapa dari mereka tidak bisa menemukan arti kata-kata sulit. Hal itu membuat siswa tidak dapat memahami teks dan dapat mengembangkan karangan yang diinstruksikan.

Pada siklus II, peneliti membuat beberapa modifikasi dalam mengajar menulis untuk memecahkan masalah siswa yang dihadapi dalam siklus I. Pertama, kosakata diajarkan dengan meminta mereka untuk menemukan makna kata-kata sulit dengan berkonsultasi dengan kamus. Jika mereka masih tidak mengerti tentang makna kata-kata sulit, guru mengatakan kepada mereka makna yang benar dari kata-kata. Hal ini dimaksudkan untuk memotivasi mereka dalam mempelajari kosakata. Kedua, para siswa diminta untuk bekerja dalam kelompok. Setiap kelompok terdiri dari 4 sampai 5 siswa. Para siswa cerdas, yang memiliki skor besar di post-test I, dipisahkan dalam setiap kelompok. Hal itu dilakukan untuk membantu siswa lain yang memiliki skor rendah dalam post-test I dalam mengembangkan karangan yang diberikan. Selain itu, pengelompokan itu dimaksudkan untuk membantu siswa menjadi yakin dengan jawaban mereka. Selain itu, dapat meminimalkan kecemasan mereka membuat kesalahan karena mereka memiliki kelompok yang dapat mendukung mereka. Ketiga, siswa yang memiliki skor rendah dalam post-test I diminta untuk menjawab pertanyaan-pertanyaan secara intensif dalam mempertanyakan bagian. Hal itu dilakukan untuk membuat mereka lebih mengerti tentang teks yang diberikan.

Akibatnya, proses belajar-mengajar berjalan dengan baik di mana banyak siswa menjadi aktif dalam kegiatan ini. Hasil kuesioner juga menunjukkan bahwa mereka memberi respon positif terhadap penerapan model pembelajaran CTL. Keberhasilan tindakan itu bisa dilihat dari hasil tes siswa.

Setelah menerapkan model pembelajaran $C T L$, skor rata-rata siswa dalam menulis adalah 78.67 pada siklus I yang meningkat 5.47 poin dari nilai rata-rata pada pre-test yaitu 73.2. Skor ini diklasifikasikan menjadi tingkat baik. Dalam post-test I terdapat $16(53 \%)$ siswa yang mendapat hasil sangat baik, 14 (47\%) siswa yang mendapat hasil baik. Meskipun siswa telah membuat perbaikan, ada beberapa siswa yang tidak bisa mencapai nilai Test Pendalaman Materi (TPM) sekolah ( $\geq 77$ ). Karena itu siklus berikutnya akan dilakukan agar semua siswa dapat mencapai TPM yang ditentukan oleh sekolah.

Aksi dilanjutkan ke siklus II, karena nilai siswa tidak mencapai indikator keberhasilan (studi akan dianggap berhasil jika 100\% siswa telah lulus standar nilai kelulusan $(\geq 77)$ ). Nilai rata-rata siswa adalah 83.333, yang dapat dikategorikan sangat baik. Nilai tersebut meningkat 4.7 poin dari nilai rata-rata pada siklus I. Dalam post-test 2 ini, juga ditemukan bahwa ada 4 (13\%) siswa yang mendapat hasil yang sempurna, 23 (77\%) siswa yang mendapat kategori sangat baik, dan hanya $3(10 \%)$ siswa yang dikategorikan baik. Semua siswa dapat melampui TPM yang ditetapkan oleh siswa.

Fakta-fakta tersebut sejalan dengan beberapa penelitian yang dilakukan oleh peneliti lain. Mereka telah menerapkan model pembelajaran CTL saatmengajar kemampuan menulis. Syahraini (2014) membuat studi tentang penerapan model pembelajaran $C T L$ yang efektif dapat meningkatkan prestasi siswa dalam memahami materi. Model pembelajaran CTL telah terbukti membantu untuk meningkatkan prestasi siswa dalam memahami materi pada siswa SMP dan SMA. Semua murid-muridnya bisa mencapai passing grade sekolah. 
Satriani (2012) juga menerapkan strategi ini untuk siswa SMP dan SMA. Mereka menemukan bahwa siswa mereka lebih termotivasi dalam menulis model pembelajaran ini memberikan kesempatan bagi mereka untuk mengakses pengetahuan mereka sebelumnya, belajar dari pemodelan guru dan siswa memberikan umpan balik mereka sendiri. Dan sebagai hasilnya, para siswa bisa mencapai passing grade sekolah dan memberikan respon positif terhadap penerapan model pembelajaran CTL pada pengajaran menulis di kelas.

Dapat disimpulkan bahwa model pembelajaran $C T L$ merupakan salah satu model pembelajaran inovatif yang dapat membantu siswa ketika belajar dalam kelas menulis.

\section{SIMPULAN}

Berdasarkan temuan yang telah dipaparkan di atas dapat disimpulkan bahwa penerapan model pembelajaran $C T L$ dapat membantu para siswa, terutama siswa IX B5 SMP Negeri 4 Singaraja untuk meningkatkan kompetensi mereka dalam menulis. Hal ini dapat dilihat sebagai dari peningkatan keterampilan siswa dalam menulis yang terlihat jelas dari nilai rata-rata siswa pada setiap siklus. Skor rata-rata siswa di pre-test adalah 73,2 . Kemudian meningkat 5,47 poin menjadi 78.67 pada siklus I. Rata-rata tersebut diklasifikasikan ke dalam tingkat penguasaan baik. Meskipun nilai rata-rata siswa telah mencapai TPM sekolah, tidak semua siswa mampu mencapai TPM tersebut $(\geq 77)$. Karena itu, peneliti memodifikasi model CTL ini agar semua siswa dapat mencapai TPM sekolah. Dan hasilnya, semua siswa bisa mencapai TPM. Skor rata-rata siswa di post-test II meningkat 4,7 poin menjadi 83.33 dibandingkan siklus I.

Sejalan dengan peningkatan siswa dari nilai rata-rata dalam tes, hasil observasi menunjukkan bahwa para siswa memberikan respon positif terhadap penerapan model pembelajaran $C T L$.

Dari hasil tersebut implikasi yang dapat diberikan adalah para siswa dapat mencoba model pembelajaran $C T L$ dalam kegiatan menulis karena model pembelajaran ini menawarkan banyak keuntungan terhadap keterampilan menulis siswa, misalnya bisa mendorong siswa untuk menjadi lebih kooperatif dan bertanggung jawab dalam menyelesaikan tugas yang diberikan oleh guru. Selain itu, guru dapat menerapkan model pembelajaran CTL sebagai model pembelajaran yang inovatif dalam mengajar kemampuan menulis.

\section{REFERENSI}

Campbell, A. 2002. Freewriting Techniques. Copyright Lynchburg College: Online Source

Chakraverty, A. and Gautum K. 2000. Dynamic of Writing. Available at http://exchanges.state.gov/forum/vols38/no3/pp22.htm retrieved on July 10, 2018

Goodrich, H. 1997. Student Self-Assessment: At the Intersection of Metacognition and Authentic Assessment. Harvard: Harvard University

Kemmis, S. \& McTaggart. R. 1988. The Action Research Planner. Victoria: Deakin 
University

Raimes, R. 1983. Techniques in Teaching Writing. New York: Oxford University Press

Rudiyanto, M. 2009. The Implementation of Contextual Teaching and Learning in English Class. Jurnal OKARA. 2(4), 25-32.

Satriani, I. 2012. Contextual Teaching and Learning Approach to Teach Writing. Indonesian Journal of Applied Linguistics. 2(1), 10-22

Suyanto, K.E. 2003. Pengajaran dan Pembelajaran Kontekstual. Malang: Universitas Negeri Malang.

Slavin, R.E. 1999. Cooperative Learning : Theory, Research, and Practice. Boston: Allyn and Bacon.

Syahraini, E. 2014. Peningkatan Keterampilan Menulis Teks Berita Melalui Pendekatan Kontekstual Siswa Kelas VIII H SMP Negeri 4 Tambang Kabupaten Kampar. Jurnal Bahasa, Sastra dan Pembelajaran. 2(2), 88-100 